\title{
"PENGARUH KOMPENSASI DAN DISIPLIN KERJA TERHADAP KINERJA GURU SMA NEGERI 6 BANDA ACEH"
}

\author{
Oleh : Febyolla Presilawati SE.MM.
}

\begin{abstract}
ABSTRAK
Dalam pengelolaan manajemen sekolah terlihat ada masalah dalam hal penurunan kinerja guru jika dibandingkan dengan tahun sebelumnya. Hal ini diduga dipengaruhi oleh berbagai faktor antara lain kompensasi dan disiplin kerja. Tertarik pada masalah tersebut, maka penelitian ini bertujuan untuk mendeskriptifkan, menganalisis dan mengetahui pengaruh paling dominan dari kompensasi, disiplin kerja terhadap kinerja guru di SMA 6 Negeri Banda Aceh.

Untuk menganalisis masalah tersebut, maka digunakan 40 responden melalui metode sampling. Teknik pengumpulan data menggunakan metode survei dengan alat bantu kuesioner. Analisis data dilakukan dengan uji validitas, uji reliabilitas, analisis deskriptif dan analisis regresi linear berganda. Proses pengolahan data menggunakan aplikasi software SPSS Versi 21.00. Hasil penelitian menunjukan bahwa analisis koefisien regresi Variabel Kompensasi $=0.022$, Disiplin Kerja $=0.000$ berpengaruh signifikan terhadap kinerja. Disiplin merupakan variabel yang paling dominan pengaruhnya terhadap kinerja dengan nilai beta 0.593 .

Dari hasil penelitian ini, ada beberapa hal yang dapat disarankan dalam rangka meningkatkan kinerja guru, yaitu antara lain prinsip keadilan dalam pemberian kompensasi langsung maupun tidak langsung, Mematuhi dan menjungjung peraturan yang berlaku yang telah disepakati bersama dalam sekolah untuk meningkatkan disiplin kerja guru.

Kata kunci : Kompensasi, Disiplin Kerja, dan Kinerja Guru.
\end{abstract}

\section{PENDAHULUAN}

\subsection{Latar Belakang Masalah}

Sekolah sebagai lembaga formal pendidikan memegang peranan penting dalam meningkatkan kualitas pendidikan melalui proses pembelajaran untuk menunjang kelancaran jalannya pembangunan di Indonesia secara keseluruhan. Pembelajaran merupakan kegiatan utama sekolah sebagai bentuk layanan pendidikan bagi masyarakat. Sekolah diberi kebebasan 
memilih strategi, metode, dan teknik pembelajaran yang sesuai dengan karakteristik mata pelajaran, siswa, guru, dan kondisi nyata sumber daya, yang tersedia di sekolah. Secara umum, metode pembelajaran yang berpusat pada siswa (student centered) lebih mampu memberdayakan pembelajaran siswa.

SMA Negeri 6 Banda Aceh adalah Sekolah SMA Negeri yang terletak di Provinsi Aceh, Banda Aceh. Proyek tunggal dari SMA Negeri 6 Banda Aceh itu sendiri adalah membangun pendidikan yang beragama islam. SMA Negeri 6 Banda Aceh mempunyai guru 40 orang dan mempunyai murid 240 siswa. SMA Negeri 6 Banda Aceh sudah berkecimpung dalam dunia pendidikan selama 15 tahun ternyata masih memiliki kendala seperti apa yang dipaparkan dari hasil wawancara dengan kepala sekolah SMA Negeri 6 Banda Aceh pada awal tahun 2016. Masalah yang ditemukan di SMA Negeri 6 Banda Aceh yaitu, Kompensasi yang masih menjadi salah satu faktor yang paling dominan dalam memotivasi seseorang untuk meningkatkan kinerjanya.

Kinerja dapat pula diartikan sebagai prestasi kerja atau pelaksanaan kerja, sebagai suatu kesuksesan yang dihasilkan seseorang dalam melaksanakan suatu pekerjaan menurut ukuran yang berlaku, dalam kurun waktu tertentu berkaitan dengan pekerjaan serta perilaku dan tindakannya. Keunggulan kompetitif guru akan tercapai apabila pihak manajemen dapat mengelola jantung aktivitas sekolah dengan mendorong sumber daya manusianya, karena pada dasarnya guru tersebut merupakan komponen penting bagi sekolah untuk menciptakan daya saing yang berkualitas. Maka berhasil atau tidaknya suatu organisasi dalam mewujudkan tujuannya sangat tergantung pada sumber daya manusia yang dimilikinya. Meskipun suatu sekolah memiliki sumber daya lain yang baik, peralatan kerja yang canggih, metode yang bagus maupun anggaran dana yang banyak, tetapi apabila sumber daya manusia yang dimiliki tidak berkualitas dan tidak mendapatkan pengelolaan yang serius, maka organisasi akan mengalami kesulitan dalam mencapai tujuannya.

Mangkuprawira (2009:218) Kinerja merupakan hasil atau tingkat keberhasilan seseorang secara keseluruhan selama periode tertentu di dalam melaksanakan tugas dibandingkan dengan berbagai kemungkinan, seperti standar hasil kerja, target atau sasaran atau kriteria yang telah ditentukan terlebih dahulu dan telah disepakati bersama. Jika dilihat asal katanya kata kinerja adalah terjemahan dari kata performance, dengan beberapa "entries" yaitu: 1) melakukan, menjalankan, melaksanakan; 2) memenuhi atau melaksanakan kewajiban suatu niat atau nazar; 3) melaksanakan atau menyempurnakan tanggungjawab; dan 4) melakukan sesuatu yang diharapkan oleh seseorang.

Kinerja sekolah adalah hasil kerja yang dicapai oleh sekolah, dalam hal ini sekolah dapat mencapai target sekolah unggul yang diharapkan, sehingga kinerja sekolah menjadi hal yang penting untuk menjadi ukuran untuk meningkatkan semangat agar sekolah menjadi lebih berkembang lagi. Sedangkan kinerja guru adalah hasil kerja yang dicapai oleh guru sesuai dengan tanggung jawab dan wewenangnya sebagai seorang guru atau pengajar dalam rangka mencapai tujuan secara baik. Kinerja guru ini merupakan faktor pendukung yang sangat penting di dalam sekolah untuk berkembangnya dan dapat bersaing dengan sekolah lain, bahkan sekolah menjadi yang terdepan dari tahun ketahun.

Kompensasi guru adalah bentuk imbalan dan penghargaan yang berhak diterima guru baik yang berupa imbalan langsung maupun tak langsung sebagai balas jasa atas prestasi dan kinerja guru. Adanya kompensasi menjadi stimulus bagi guru untuk meningkatkan prestasi kerja. Sistem pemberian kompensasi yang tepat dan sesuai sasaran menjamin kesejahteraan guru. Adanya kompensasi tinggi yang diberikan kepada guru dapat meningkatkan kinerja guru. Berdasarkan analisis deskriptif kompensasi yang diterima guru SMA Negeri 6 Banda Aceh dalam kategori baik, dan dari hasil penelitian adanya kompensasi langsung dan kompensasi tidak langsung berpengaruh positif terhadap kinerja guru. Dengan adanya kompensasi langsung yang diterima guru SMA Negeri 6 Banda Aceh, seperti menerima gaji yang utuh pada 
tanggal yang sama dan rutin setiap bulan maka kinerja guru pun mengalami peningkatan. Selain itu dengan tetap menerima gaji utuh walaupun pada bulan tersebut ada suatu waktu guru berhalangan hadir, hal tersebut membuat kinerja guru semakin meningkat.

Disiplin kerja merupakan tindakan seorang guru untuk mematuhi peraturan-peraturan yang telah disepakati bersama. Tindakan ini bila dilakukan secara benar dan terus menerus akan menjadi kebiasaan yang tertanam dalam perilaku guru dan akan membantu tercapainya kinerja guru yang diharapkan institusi. Berdasarkan analisis deskriptif disiplin kerja guru SMA Negeri 6 Banda Aceh dalam kategori baik. Hal ini terbukti dari hasil penelitian, dimana guru yang masuk kelas dan meninggalkan sekolah tepat waktu serta mampu menyelesaikan materi pelajaran sesuai dengan Rencana Pelaksanaan Pembelajaran (RPP) maka kinerjanya pun meningkat.

Adapun keterangan dari kuesioner yang dilakukan peneliti dengan 40 guru ada beberapa hal yang saat ini terjadi yaitu kinerja, kompensasi belum sesuai dengan yang diharapkan oleh para guru. Peneliti juga melakukan wawancara terbuka dengan tiga siswa bahwa keterangan yang didapat adalah masih adanya sebagian guru yang sering terlambat saat masuk kelas dan ada juga yang datang ke sekolah diwaktu jam mengajar saja dan masih ada guru yang diluar kelas saat jam mengajar.

Berdasarkan masalah diatas maka penelitian yang diambil berjudul "Pengaruh Kompensasi Dan Disiplin Kerja Terhadap Kinerja Guru SMA Negeri 6 Banda Aceh"

\subsection{Rumusan Masalah}

Rumusan masalah yang diajukan dalam penelitian ini didasarkan pada uraian diatas sebagai berikut :

a. Apakah terdapat pengaruh kompensasi terhadap kinerja guru di SMA Negeri 6 Banda Aceh?

b. Apakah terdapat pengaruh disiplin kerja terhadap kinerja guru di SMA Negeri 6 Banda Aceh?

c. Apakah terdapat pengaruh kompensasi dan disiplin kerja secara simultan terhadap kinerja guru di SMA Negeri 6 Banda Aceh?

\subsection{Tujuan Penelitian}

Dilihat dari keterbatasan ini dan rumusan masalah yang telah ditetapkan diatas penelitian ini bertujuan untuk mengetahui faktor-faktor penting yang mempengaruhi kompensasi dan disiplin kerja terhadap kinerja guru.

1. Untuk mengetahui pengaruh kompensasi terhadap kinerja guru di SMA Negeri 6 Banda Aceh.

2. Untuk mengetahui pengaruh disiplin kerja terhadap kinerja guru di SMA Negeri 6 Banda Aceh.

3. Untuk mengetahui pengaruh kompensasi dan disiplin kerja secara simultan terhadap kinerja guru di SMA Negeri 6 Banda Aceh.

\subsection{Manfaat Penelitian}

Berdasarkan tujuan penelitian, maka manfaat dalam penelitian ini adalah :

1. Bagi peneliti, penelitian ini diharapkan dapat memberikan wawasan dan pemahaman kepada penulis mengenai sistem penghargaan dan sistem pengukuran kinerja dalam meningkatkan kinerja karyawan. 
2. Bagi UNMUHA, penelitian ini dapat memberikan kontribusi bagi pengembangan ilmu manajemen, khususnya manajemen sumber daya manusia dan menyajikan bukti-bukti empiris serta teori-teori baru bagi penelitian yang akang datang.

3. Bagi SMA Negeri 6 Banda Aceh, penelitian ini dapat menjadi bahan masukan dan pertimbangan dalam penerapan sistem penilaian kinerja dan pemberian penghargaan sehubungan dengan peningkatan kinerja pegawai.

\subsection{Ruang Lingkup Penelitian}

Dengan memperhatikan latar belakang masalah tersebut diatas, maka dapat

ruang lingkup penelitian sebagai berikut :

1. Kompensasi yang diterima belum sepenuhnya sesuai dengan apa yang diharapkan, seperti sebagian guru merasa gaji yang diterima masa kecil dibandingkan dengan gaji guru sekolah lain yang setara dengan SMA Negeri 6 Banda Aceh.

2. Disiplin kerja yang dimiliki sebagian guru masih rendah, seperti masih ada sebagian guru yang belum tepat waktu saat masuk kantor ataupun saat masuk kelas untuk melaksanakan kewajiban mengajar yang mengakibatkan tidak maksimalnya kinerja yang ditunjukan.

3. Kinerja sebagian guru belum optimal, seperti masih ada sebagian guru yang jurang inisiatif dalam mengajar, kurang mengomunikasikan perkembangan kurikulum dalam mengajar.

\section{TINJAUAN PUSTAKA}

\subsection{Kinerja Guru}

\subsubsection{Pengertian Kinerja}

Kinerja ialah suatu gambaran yang sistematis tentang kebaikan dan kelemahan dari pekerjaan individu atau kelompok. Meskipun ada diantara masalah teknis (seperti pemilihan format) dan masalah manusianya itu sendiri (seperti resistansi penilai, dan adanya hambatan hubungan antar individu), yang kesemuanya itu tidak akan dapat teratasi oleh penilai kinerja.

Kinerja pegawai (performance) adalah kuantitas dan atau kualitas hasil kerja individu atau kelompok dalam melaksanakan tugas pokok dan fungsi yang berpedoman pada norma, standar operasional prosedur, kriteria dan ukuran yang telah ditetapkan atau yang berlaku dalam organisasi. Veithzal Rivai (2011:548) menjelaskan kinerja merupakan suatu fungsi dari motivasi dan kemampuan adalah sebagai berikut: "untuk menyelesaikan tugas atau pekerjaan, seseorang sepatutnya memiliki derajat kesediaan dan tingkat kemampuan tertentu. Kinerja merupakan perilaku nyata yang ditampilkan setiap orang sebagai prestasi kerja dan juga merupakan suatu hal yang sangat penting dalam upaya perusahaan dalam mencapai tujuan”.

Kemudian pengertian kinerja menurut Mathis dan Jackson (2010:329) adalah "apa yang dilakukan atau tidak dilakukan oleh karyawan. Kinerja karyawan adalah seberapa banyak mereka memberi kontribusi kepada organisasi antara lain :kuantitas output, jangka waktu output, kehadiran di tempat kerja dan sikap koorporatif."

\subsubsection{Faktor-faktor Yang Mempengaruhi Kinerja}

Karena karyawan bekerja dalam lingkungan kerja yang bergerak secara dinamis. Maka banyak faktor yang ikut mempengaruhi kinerja atau prestasi kerja mereka, disamping faktor individu, kinerja karyawan juga dipengaruhi oleh faktor organisasi. Menurut Mathis dan Jackson (2010:123) ada tiga faktor yang berperan dalam kinerja individu. Faktor-faktor tersebut adalah "(1) kemampuan individu untuk melakukan pekerjaan tersebut, (2) tingkat usaha yang dicurahkan, dan (3) dukungan organisasi. Hubungan ketiga faktor ini diakui secara luas dalam berbagai literatur manajemen sebagai : Kinerja (Performance-P) $=$ Kemampuan $($ Ability-A) $\mathrm{x}$ Usaha (Effort-E) x Dukungan (Support-S)". 
Byar dan Rue dalam Sutrisno (2013) mengatakan bahwa dua faktor yang mempengaruhi prestasi kerja adalah faktor individu dan lingkungan. Faktor-faktor yang dimaksud adalah :

1. Faktor individu

a. Usaha (effort) yang menunjukkan sejumlah sinergi fisik dan mental yang digunakan dalam menyelenggarakan gerakan tugas.

b. Abilitys yaitu sifat-sifat personal yang diperlukan untuk melaksanakan suatu tugas.

c. Role yaitu segala perilaku dan aktivitas yang dirasakan perlu oleh individu untuk menyelesaikan suatu pekerjaan.

2. Faktor lingkungan
a. Kondisi fisik,
b. Peralatan,
c. Waktu,
d. Material,
e. Pendidikan,
f. Supervisi,
g. Desainer struktur organisasi.
h. Pelatihan
i. Keberuntungan

\subsubsection{Indikator Pengukuran Kinerja}

Ada banyak indikator dan standar yang diterapkan dalam pengukuran kinerja dan sangat ditentukan oleh tingkat kepentingan, sifat pekerjaan serta karakteristik pekerjaan yang dilakukan. Menurut Mathis dan Jackson (2010:123) kinerja dapat di ukur dari 3 (tiga) aspek yaitu :

"Ada tiga aspek yang terlibat dalam membentuk kinerja individu. Komponen tersebut adalah" (1) kemampuan individu untuk melakukan pekerjaan tersebut, (2) tingkat usaha yang dicurahkan, dan (3) dukungan organisasi”.

Kemudian Bernardin dan Russel dalam Sutrisno (2013:179) mengajukan enam kriteria primer yang dapat digunakan untuk mengukur kinerja, yaitu :

1. Hasil kerja : tingkat kuantitas maupun kualitas yang telah dihasilkan dan sejauh mana pengawasan dilakukan.

2. Pengetahuan pekerjaan : pengetahuan yang terkait dengan tugas pekerjaan yang akan berpengaruh langsung terhadap kuantitas dan kualitas hasil kerja.

3. Inisiatif : tingkat inisiatif selama melaksanakan tugas pekerjaan khususnya dalam hal penanganan masalah-masalah yang timbul.

4. Kecekatan mental : tingkat kemampuan atau kecepatan dalam menerima instruksi pekerjaan dan menyesuaikan dengan cara kerja serta situasi kerja yang ada.

5. Sikap : sikap positif dalam melaksanakan tugas pekerjaan.

6. Disiplin waktu dan absensi : tingkat ketetapan waktu dan kehadiran.

Bernandin dan Rusel dalam Darmawan (2013:192) mengemukaan ada 6 (enam) kriteria yang dapat digunakan dalam mengukur kinerja antara lain :

1. Quality, merupakan tingkat sejauh mana proses atau hasil pelaksanaan kegiatan mendekati kesempurnaan atau mendekati tujuan yang diharapkan.

2. Quantity, merupakan jumlah yang dihasilkan misalkan jumlah moneter, jumlah unit, atau jumlah siklus kegiatan yang diselesaikan.

3. Timeliness, merupakan lamanya suatu kegiatan diselesaikan pada waktu yang di kehendaki dengan memperhatikan jumlah output lain serta waktu yan tersedia untuk kegiatan lain.

4. Cost effectiveness, besarnya penggunaan sumber daya organisasi guna mencapai hasil yang maksimal atau pengurangan kerugian dari setiap unit penggunaan sumber daya. 
5. Need for supervision, kemampuan kayawan untuk melaksanakan fungsi pekerjaan tanpa perlu adanya supervise untuk mencegah tindakan yang tidak diinginkan.

6. Interpersonal impact, kemampuan seorang karyawan untuk memelihara harga diri, nama baik dan kemampuan kerja sama di antara rekan kerja dan bawahan.

\subsection{Sistem Pengukuran Kinerja}

\subsubsection{Pengertian Pengukuran Kinerja}

Pengukuran kinerja (Performance Apprasial) memainkan peranan yang sangat penting dalam peningkatan motivasi di tempat kerja. Pengawai menginginkan dan membutuhkan balikan berkenaan dengan prestasi kerja mereka dan pengukuran menyediakan kesempatan untuk memberikan balikan kepada mereka. Apabila prestasi kerja tidak sesuai dengan standar, maka pengukuran menyediakan kesempatan untuk meninjau kemajuan pegawai dan untuk menyusun rencana peningkatan prestasi kerja (Dessler, 2010:536). Pengukuran kinerja merupakan kajian sistematis tentang kondisi kerja pegawai yang dilaksanakan secara formal yang dikaitkan dengan dtandar kerja yang telah ditentukan perusahaan (Rivai, 2011:18).

Beberapa pengertian pengukuran kinerja menurut Darmawan (2013:178) adalah :

1. Pengukuran kinerja adalah usaha mengidentifikasi atau menilai dan mengelola kinerja.

2. Pengukuran kinerja adalah usaha mengidentifikasi atau menilai aspek-aspek kinerja yang berpengaruh terhadap keberhasilan perusahaan dalam mencapai tujuan.

3. Pengukuran kinerja adalah kegiatan mengukur atau menilai untuk menetapkan seorang karyawan sukses atau gagal untuk melaksanakan pekerjaannya dengan menggunakan standar pekerjaan tolak ukur.

4. Pengukuran kinerja merupakan kegiatan kontrol atau pengawasan dan bukan pula mencari-cari kesalahan untuk memberikan sanksi.

Pengukuran kinerja sebenarnya lebih terkait dengan persoalan individu pegawai, karena sinyal-sinyal dari hasil pengukuran kinerja secar emosional terkadang akan mempengaruhi harga diri mereka, namun kondisi bukan tujuan yang ingin dicapai oleh perusahaan, melainkan sebagai sarana untuk memasuki masa depan yang lebih.

Bagian kepegawaianlah yang secara terpusat bertanggungjawab untuk mengembangkan sistem pengukuran kinerja bagi semua satuan kerja dalam organisasi. Tujuan utama dan pemusatan tugas ini dibagian kepegawainan ialah untuk menjamin keseragaman yang tidak hanya tercermin pada objektivitas, akan tetapi juga mempermudah pendokumentasian. Dalam hubungan pendokumentasian dapat ditambahkan bahwa dewasa ini banyak organisasi yang sudah mengembangkan sistem informasi kepegawaian dengan memanfaatkan batuan komputer.

\subsubsection{Tujuan Pengukuran Kinerja}

Tujuan pengukuran kinerja menurut Rivai (2011:311) yaitu :

1. Mengetahui pengembangan, yang meliputi (a) Identifikasi kebutuhan pelatihan, (b) Umpan balik kinerja, (c) Menentukan transfer dan penugasan, dan (d) Identifikasi kekuatan dan kelemahan pegawai.

2. Pengambilan keputusan administratif, yang meliputi : (a) Keputusan untuk menentukan kebutuhan pelatihan, (b) Pengakuan kinerja pegawai, (c) Pemutusan hubungan kerja dan (d) Mengidentifikasi yang buruk.

3. Keperluan perusahaan, yang meliputi : (a) Perencanaan SDM, (b) Menentukan kebutuhan pelatihan, (c) Evaluasi pencapaian tujuan perusahaan, (d) Informasi untuk identifikasi tujuan, (e) Evaluasi terhadap sistem SDM, dan (f) Penguatan terhadap kebutuhan pengembangan perusahaan.

4. Dokumentasi, yang meliputi : (a) Kriteria untuk validasi penelitian, (b) Dokumentasi keputusan-keputusan tentang SDM, dan (c) membantu untuk memenuhi persyaratan hukum. 


\subsubsection{Kegunaan Pengukuran Kinerja}

Suatu rancangan yang objektif, sistematis dan menyeluruh kepada pengukuran kinerja dapat menjadi suatu alat yang berguna bagi organisasi khususnya dlam bidang pengawasan dan pengembangan sumber daya manusia. Pengukuran kinerja bukan hanya saja menjadi suatu alat bagi manajemen dalam menseleksi dan mengidentifikasi untuk kenaikan pangkat atau gaji pegawai akan tetapi juga dapat dipakai sebagai kegiatan pelatihan untuk membantu pegawai pada segala jenjang organisasi dalam meningkatkan prestasinya serta untuk perencanaan karier pegawai dalam jangka panjang. Pengukuran kinerja juga dapat dipakai untuk memilih secara bijaksana orang-orang yang patut dipindahkan dari posisi yang satu ke posisi yang lain, atau untuk mengisi suatu lowongan pada jalur jabatan baru.

Secara umum manfaat pengukuran kinerja menurut Darmawan (2013:178) adalah :

1. Sebagai masukan bagi para pemimpin untuk membantu dan mengarahkan karyawan untuk memperbaiki kinerja.

2. Untuk melaksanakan perbaikan dan penyempurnaan kegiatan manajemen SDM lainnya seperti :

a. Menyelaraskan gaji/upah atau insentif bagi karyawan yang berprestasi.

b. Memperbaiki kegiatan penempatan, promosi, mutasi dan demosi berdasarkan prestasi.

c. Membantu pengambilan keputusan dalam untuk memilih karyawan yang akan diikut sertakan dalam pelatihan.

d. Memberikan informasi bagi karyawan untuk menyusun perencanaan karier.

e. Hasil pengukuran kinerja dapat digunakan untuk mendiagnosa masalah-masalah organisasi.

Dengan demikian pengukuran kinerja menjadi kebijakan penting untuk mengarahkan dan mengontrol kinerja, sehingga dapat menyesuaikan keselarasan antara kinerja pegawai dengan perkembangan lingkungan organisasi sehingga dapat mengakomodasi kebutuhan perusahan untuk menciptakan keunggulan yang lebih kompetitif. Pengukuran kinerja juga dapat dijadikan acuan untuk meningkatkan pendidikan dan pelatihan pegawai, dasar pembayaran dan kenaikan gaji, pengembangan karier atau memberi penghargaan bagi pegawai yang berhasil. Dengan demikian pengukuran kinerja akan sama-sama akan mengintergrasikan tujuan individu maupun perusahaan.

\subsubsection{Elemen dan Proses Pengukuran}

Bila pengukuran kinerja harus dihubungkan dengan usaha pencapaian kinerja yang diharapkan, maka harus adanya berbagai elemen dalam pengukuran kinerja. Menurut Darmawan (2013:180) ada beberapa elemen pokok yang perlu diperhatikan dalam pengukuran kinerja antara lain :

1. Penentuan sasaran.

2. Penentuan standar.

3. Penentuan metode dan pelaksanaan pengukuran.

4. Evaluasi pengukuran.

Pengukuran kinerja harus didukung dengan penentuan sasaran kerja yang spesifik, terukur pada waktu tertentu. Kemudian untuk menunjang objektivitas pengukuran kinerja maka pengukuran harus dilakukan berdasarkan standar yang telah ditetapkan. Memiliki standar berarti memiliki dimensi-dimensi yang menunjukkan perilaku kerja yang sedang dinilai, yang umumnya diterjemahkan dari sasaran kerja seperti berapa tugas harus diselesaikan, kepatuhan, tingkat kehadiran, kuantitas dan kualitas pekerjaan, kepatuhan terhadap prosedur dan lainnya.

\subsubsection{Faktor-faktor Yang Mempengaruhi Pengukuran Kinerja}


Atasan sering tidak berhasil untuk merendam emosi dalam menilai prestasi kinerja pegawai, hal ini menyebabkan pengukuran menjadi bias. Bias adalah distorsi pengukuran yang tidak akurat. Bias ini mungkin terjadi sebagai akibat ukuran-ukuran yang digunakan bersifat subjektif. Berbagai faktor yang umum terjadi dalam mempengaruhi pengukuran kinerja menurut Rivai (2011:318) adalah :

1. Kendala hukum/legal

Pengukuran kinerja harus bebas dari diskriminasi tidak sah atau tidak legal. Apa pun format pengukuran kinerja yang digunakan oleh departemen SDM harus sah dan dapat dipercaya. Jika hal tersebut tidak dipenuhi, keputusan penempatan mungkin ditentang sebab melanggar hukum ketenaga kerjaan atau hukum lainnya. Keputusan yang tidak tepat mungkin dapat terjadi kasus pemecatan yang diakibatkan kelalaian.

2. Bias oleh penilai (atasan)

Setiap masalah yang didasarkan pada ukuran subjektif adalah peluang terjadinya bias. Bentuk-bentuk bias yang umumnya terjadi adalah :

a. Hallo Effect. Terjadinya Hallo Effect ketika pendapat pribadi penilai (penyelia) mempengaruhi pengukuran kinerja baik dalam arti positif maupun negatif. Sebagai contoh seorang penilai bisa saja secara pribadi tidak menyenangi pegawai tertentu, terlepas dan faktor-faktor penyebab ketidak senangannya itu.

b. Kesalahan kecenderungan terpusat. Beberapa penilai tidak suka menempatkan pegawai ke posisi ekstrim dalam arti ada pegawai yang dinilai sangat positif atau negatif.

c. Bias karena terlalu lunak dan terlalu keras. Bias karena terlalu lunak terjadi ketika penilai cenderung begitu mudah dalam mengevaluasi kinerja pegawai. Penilai melihat semua kinerja pegawainya bagus dan menilai dengan baik.

d. Bias karena penyimpangan lintas budaya. Setiap penilai mempunyai harapan tentang tingkah laku manusia yang didasarkan pada kulturnya. Ketika seorang penilai diharuskan untuk menilai dan pegawai yang berbeda kulturnya, mereka mungkin menerapkan budayanya terhadap pegawai tersebut.

e. Prasangka pribadi. Sikap tidak suka seorang penilai terhadap sekelompok orang tertentu dapat mengaburkan hasil pengukuran seorang pegawai.

3. Mengurangi bias pengukuran

Bias penilai dapat dikurangi melalui standar pengukuran dinyatakan secara jelas, pelatihan, umpan balik, dan pemilihan teknik pengukuran kinerja yang sesuai.

\subsection{Kompensasi}

Kompensasi merupakan segala sesuatu yang diterima dapat berupa fisik maupun non fisik dan harus dihitungdan diberikan kepada seseorang yang umumnya merupakan objek yang dikecualikan dari pajak pendapatan. Kompensasi juga diberikan dengan tujuan memberikan rangsangan dan motivasi kepada tenaga kerja untuk meningkatkan prestasi kerja, serta efisiensi dan efektivitas produksi. Oleh karna itu bila kompensasi diberikan secara benar, para karyawan akan lebih terpuaskan dan termotivasi untuk mencapai sasaran-sasaran organisasi. Akan tetapi jika para karyawan memandang kompensasi mereka tidak memadai, prestasi kerja, motivasi dan kepuasan kerja mereka bisa turun secara drastis karena memang kompensasi itu penting bagi karyawan sebagai individu karena besarnya kompensasi mencerminkan ukuran nilai karya mereka diantara para karyawan itu sendiri.

Hasibuan, (2012:118) Kompensasi adalah semua pendapatan yang berbentuk uang, barang, langsung atau tidak langsung yang diterima sebagai imbalan atas jasa yang diberikan kepada perusahaan. kompensasi berbentuk uang, artinya kompensasi dibayar dengan sejumlah uang kartal kepada karyawan bersangkutan.kompensasi berbentuk barang, artinya 
kompensasi dibayar dengan barang. Misalnya kompensasi dibayar $10 \%$ dari produk yang dihasilkan. Dijawa barat penuai padi upahnya $10 \%$ dari hasil padi yang dituainya.

Wilson Bangun, (2012:13) Kompensasi adalah sesuatu yang diterima karyawan atas jasa yang mereka sumbangkan pada pekerjaannya. Mereka menyumbangkan apa yang menurut mereka berharga, baik tenaga maupun pengetahuan yang dimiliki. Seorang pekerja sebagai tukang angkut barang merasa dihargai atas pekerjaannya. Untuk memindahkan barang dari satu tempat ke tempat lain mereka akan memperoleh balasan yang setimpal atas pekerjaannya. Sesuatu yang berharga bagi karyawan adalah pengetahuan dan keterampilan yang dimiliki dijadikan sebagai dasar dalam menuntut haknya sebagai pekerja.

Kompensasi merupakan kontra prestasi terhadap penggunaan tenaga atau jasa yang telah diberikan oleh tenaga kerja. Kompensasi merupakan jumlah paket yang ditawarkan organisasi kepada pekerja sebagi imbalan atas penggunaan tenaga kerjanya. Dilihat dari cara pemberiannya, kompensasi merupakan kompensasi langsung dan kompensasi tidak langsung. Kompensasi langsung merupakan kompensasi manajemen seperti upah dan gaji atau pay for performance seperti insentif dan Gain sharing. Sementara itu, kompensasi tidak langsung dapat berupa tunjangan atau jaminan keamanan dan kesehatan. Pemberian kompensasi dapat terjadi tanpa ada kaitannya dengan prestasi, seperti upah dan gaji. Upah adalah kompensasi dalam bentuk uang dibayarkan atas waktu yang telah dipergunakan sedangkan gaji, adalah kompensasi dalam bentuk uang yang dibayarkan atas pelepasan tanggungjawab atas pekerjaan. Upah dipergunakan untuk memberikan kompensasi kepada tenaga kerja yang kurang terampil sedangkan untuk tenaga terampil biasanya digunakan pengertian gaji.

H.Hadari Nawawi, (2011:315) Kompensasi bagi organisasi/perusahaan berarti penghargaan pada para pekerja yang telah memberikan kontribusi dalam mewujudkan tujuannya melalui kegiatan yang disebut bekerja. Dari pengertian tersebut segera terlihat adanya dua pihak yang memikul kewajiban dan tanggung jawab yang berbeda, tetapi saling mempengaruhi dan saling menentukan. Pihak pertama adalah para pekerja yang memikul kewajiban dan tanggung jawab melaksanakan kegiatan yang disebut bekerja. Sedangkan pihak kedua adalah organisasi yang memikul kewajiban dan tanggung jawab memberikan penghargaan atas pelaksanaan pekerjaan oleh pihak pertama. Kewajiban dan tanggung jawab itu muncul karena antara kedua belah pihak terdapat hubungan kerja di dalam sebuah organisasi. Dari sisi lain terlihat jiga dalam pengertian tersebut bahwa pekerjaan yang dilaksanakan itu harus relevan, sehingga merupakan kontribusi dalam usaha mewujudkan tujuan organisasi/perusahaan. pekerjaan yang dihargai dan diberi ganjaran tersebut, bukan kegiatan-kegiatan di luar upaya organisasi perusahaan untuk mencapai tujuannya.

Dari beberapa teori tersebut, maka yang menjadi dimensi kompensasi adalah kompensasi langsung dan kompensasi tidak langsung. Bentuk kompensasi langsung gaji, insentif bonus, tunjangan, buku-buku, seragam dan makan siang, sedangkan kompensasi tidak langsung jaminan kesehatan dan uang pensiun.

\subsection{Disiplin Kerja}

Salah satu usaha untuk mencapai tujuan organisasi adalah sikap disiplin. Untuk menjelaskan disiplin kerja, maka perlu diketahui pengertiannya melalui teori-teori para ahli organisasi dan manajemen. Menurut pandangan masyarakat pada umumnya, patuh terhadap peraturan atau hukum yang ada adalah disiplin. Kata disiplin berasal dari bahasa latin, Disiplin berasal dari bahasa latin disciplina, yang berarti latihan atau pendidikan kesopanan dan kerohanian, serta pengembangan tabiat.

Pengertian disiplin dapat dikonotasikan sebagai suatu hukuman, meskipun arti yang sesungguhnya tidaklah demikian. Disiplin berasal dari bahasa lain "Disciplina" yang berarti 
latihan atau pendidikan kesopanan dan kerohanian serta pengembangan sikap yang layak terhadap pekerjaan

Menurut Mangkunegara dalam Sinambella (2012:239), Disiplin Kerja merupakan ukuran aktivitas organisasi untuk memanfaatkan serta sumbangan atau kemampuan yang ada secara optimal untuk mencapai tujuan, dengan menaati segala peraturan yang telah ditetapkan dapat disimpulkan bahwa pada hakikatnya disiplin adalah memanfaatkan sumbangan kemampuan secara optimal, dengan kesadaran, kesediaan, dan kepatuhannya pada aturan dan perintah yang ditetapkan organisasi.

Ukuran Disiplin kerja diukur dengan memodifikasi indikator yang dikembangkan adalah

a. Menggunakan waktu secara efektif.

b. Datang tepat waktu.

c. Kualitas kerja baik.

d. Mengikuti prosedur dan instruksi kerja.

e. Selalu hadir.

f. Berpenampilan sopan.

Dari pengertian diatas yang telah dikemukanan, dapat dikatakan bahwa kedisiplinan karyawan itu tercermin dari sikap dan perilaku. Sikap dan perilaku itu berasal dari dalam diri karyawan maupun dari kegiatan manajemen atau latihan yang diselenggarakan oleh manajemen. Berdasarkan beberapa pengertian mengenai disiplin kerja karyawan terhadap peraturan dan ketentuan berlaku dalam unit kerja sesuai dengan kesadaran dan keinsyafan dari diri dalam melaksanakan pekerjaan.

Dari pengertian di atas dapat disimpulkan bahwa disiplin kerja adalah sikap dan perbuatan guru dalam mentaati semua pedoman dan peraturan yang telah ditentukan untuk tercapainya tujuan organisasi. Disiplin berkaitan erat dengan perilaku karyawan dan berpengaruh terhadap kinerja.

Menurut Siagian dalam Sutrisno (2013), bentuk disiplin yang baik akan tercermin pada suasana di lingkungan organisasi sekolah,yaitu:

1. Tingginya rasa kepedulian guru terhadap pencapaian visi dan misi sekolah.

2. Tingginya semangat, gairah kerja dan inisiatif para guru dalam mengajar.

3. Besarnya rasa tanggung jawab guru untuk melaksanakan tugas dengan sebaikbaiknya.

4. Berkembangnya rasa memiliki dan rasa solideritas yang tinggi di kalangan guru.

5. Meningkatkan efisiensi dan produktivitas kerja.

\subsection{Kerangka Konseptual}

Secara teoritis ada beberapa faktor yang mempengaruhi kinerja, antara lain motivasi, disiplin, etika, kompetensi, pendidikan, pelatihan, manajemen, kompensasi, gizi dan kesehatan, jaminan sosial, lingkungan iklim kerja, sarana produksi, teknologi dan kesempatan berprestasi. Diantara beberapa faktor diatas yang mempengaruhi kinerja tersebut, maka penelitian ini berfokus pada variabel yang diteliti adalah kompensasi, disiplin kerja, dan kinerja.

Berawal dari hasil indentifikasi masalah yang dilakukan penulis, maka dibuatlah penelitian yang mengkaitkan hubungan kausal variabel kompensasi, disiplin kerja, dan kinerja. Hubungan kausal antara variabel yang mempengaruhi (independen) dan variabel yang dipengaruhi (dependen) dapat digambarkan sebagai berikut :

Berdasarkan dari kajian teori-teori yang telah dikemukakan sebelumnya, maka disusunlah kerangka pemikiran: pengaruh kompensasi dan disiplin kerja terhadap kinerja 
guru di SMA Negeri 6 Banda Aceh. Hubungan antar variabel independen dengan variabel dependennya dapat dijelaskan sebagai berikut :

\section{A. Kompensasi berpengaruh terhadap kinerja guru}

Jika balas jasa yang diberikan cukup besar, maka pimpinan akan mudah memotivasi bawahannya.

\section{B. Disiplin berpengaruh terhadap kinerja guru}

Kedisiplinan adalah fungsi operatif dari MSDM yang terpenting, karena semakin baik disiplin karyawan, semakin tinggi prestasi kerja dan kinerja yang dicapainya. Tanpa disiplin karyawan yang baik, sulit bagi organisasi perusahaan mencapai hasil yang optimal. Disiplin yang baik mencerminkan besarnya tanggung jawab seseorang terhadap tugas-tugas yang diberikan kepada karyawan, maka mendorong gairah kerja, semangat kerja dan kinerja dalam mewujudkan tujuan perusahaan dan karyawan.

\section{Hubungan kompensasi terhadap kinerja}

Jika balas jasa yang diterima karyawan semakin besar berarti jabatannya semakin tinggi, statusnya semakin baik, dan pemenuhan kebutuhan yang dinikmatinya semakin banyak pula. Dengan demikian kinerja juga semakin baik.

\section{Hubungan disiplin terhadap kinerja}

Disiplin dalam bekerja merupakan faktor yang juga harus dimiliki oleh pegawai jika menginginkan tercapainya kinerja yang baik dalam suatu pekerjaannya.

\subsection{Penelitian Sebelumnya}

Pada penjelasan berikut dibawah ini ada beberapa penelitian terdahulu yang relevan sehingga dapat diketahui bahwa kesamaan variabel yang akan diteliti bila dibandingkan dengan para peneliti terdahulu terletak pada pemilihan variabel terikatnya, yaitu Kinerja dan Kepuasan Kerja.

Dalam penelitian yang dilakukan oleh Edy Suparno berjudul Pengaruh Kompetensi, Motivasi Kerja, dan Kecerdasan Emosional Guru terhadap Kinerja Guru di SMP Negeri Se-Rayon Barat Kabupaten Sragen. Tesis. Surakarta: Program Pascasarjana Universitas Muhammadiyah Surakarta, 2005. Berdasarkan hasil analisis data penelitian dapat disimpulkan bahwa : "Ada pengaruh yang signifikan kompetensi, motivasi kerja, dan kecerdasan emosional guru secara bersama-sama terhadap kinerja guru di SMP Negeri se-Rayon Barat Kabupaten Sragen" dapat dibuktikan kebenarannya. Hal tersebut ditunjukkan dengan $\mathrm{F}$ hitung $=58,340>\mathrm{F}$ tabel $=2,66$ pada taraf signifikansi 5\%. Sumbangan efektif kompetensi guru sebesar $12,100 \%$; sumbangan efektif motivasi kerja guru sebesar $29,000 \%$, sumbangan efektif kecerdasan emosional guru sebesar $13,600 \%$; dan sumbangan efektif secara simultan sebesar 47,700\%; (2) "Ada pengaruh yang signifikan kompetensi guru terhadap kinerja guru di SMP Negeri se-Rayon Barat Kabupaten Sragen" dapat dibuktikan kebenarannya. Hal tersebut ditunjukkan dengan hasil perhitungan $\mathrm{t}_{1}=4,788>\mathrm{t}$ tabel $=1,960$ pada taraf signifikansi 5\%; (3) "Ada pengaruh yang signifikan motivasi kerja guru terhadap kinerja guru di SMP Negeri se- Rayon Barat Kabupaten Sragen" dapat dibuktikan kebenarannya. Hal tersebut ditunjukkan dengan hasil perhitungan $\mathrm{t}_{2}=9,673>\mathrm{t}_{\text {tabel }}=1,960$ pada taraf signifikansi $5 \%$; (4) "Ada pengaruh yang signifikan kecerdasan emosional guru terhadap kinerja guru di SMP Negeri se-Rayon Barat Kabupaten Sragen" dapat dibuktikan kebenarannya. Hal tersebut ditunjukkan dengan hasil perhitungan $\mathrm{t}_{3}=6,087>\mathrm{t}_{\text {tabel }}=1,960$ pada taraf signifikansi $5 \%$.

Penelitian Marsana berjudul Pengaruh Kompetensi dan Motivasi Kerja Terhadap Kepuasan Kerja Serta Implikasinya Pada Kinerja Guru (Studi Kasus pada SMA Negeri Se Sub Rayon 1 Semarang). Hasil penelitian terhadap 72 responden variabel kompetensi memiliki nilai (sig. $=0,003$ ) lebih kecil dari $\alpha 0,05$ maka variabel kompetensi berpengaruh positif terhadap kepuasan kerja, sehingga hipotesis 1 (H1) terbukti dan dapat 
diinterpretasikan bahwa meningkatnya kompetensi akan dapat meningkatkan kepuasan kerja guru SMA Negeri Se Sub Rayon 1 Semarang.

Dalam penelitian yang dilakukan oleh Sugiarso Pranoto menunjukan bahwa variabel kompensasi signifikan sebesar 0.006, variabel gaya kepemimpinan signifikan sebesar 0.012, variabel promosi signifikan sebesar 0.014, sedangkan variabel lingkungan kerja signifikan sebesar 0.009. hal ini berarti bahwa kompensasi, gaya kepemimpinan, promosi dan lingkungan kerja berpengaruh terhadap kepuasan kerja. Kompensasi merupakan variabel yang paling dominan pengaruhnya terhadap kepuasan kerja.

Dalam penelitian yang dilakukan oleh Endang Ilyas, yang berjudul Pengaruh Kompensasi, Promosi dan Shif Kerja terhadap Kepuasan Kerja dan Kinerja Pengumpul Tol Gerbang Karang Tengah dan Ramp Kebon Jeruk PT Jasa Marga Tbk Cabang JakartaTangerang. Hasil analisis menunjukan bahwa variabel kompensasi nilai signifikan 0.000 yang lebih kecil dari nilai $\alpha 0,05$ maka variabel kompensasi berpengaruh signifikan terhadap kepuasan kerja. Dan dari hasil pengolahan data dari tabel coefficients didapatkan variabel kompensasi memiliki nilai signifikan 0.000 yang lebih kecil dari nilai nilai $\alpha 0,05$ maka variabel kompensasi berpengaruh signifikan terhadap kinerja.

Penelitian yang dilakukan oleh Sita Dewi 2012, yang berjudul Pengaruh Motivasi dan Disiplin Kerja Terhadap Kepuasan Kerja Guru SMP Negeri 1 Wedi Kabupaten Klaten. Hasil penelitian terhadap 55 responden bahwa menunjukan variabel motivasi memiliki nilai sig. $=0,000$ lebih kecil dari $\alpha$ 0,05 maka variabel motivasi berpengaruh positif terhadap kepuasan kerja guru, dan variabel disiplin kerja memiliki nilai sig. $=0,025$ lebih kecil dari $\alpha 0,05$ maka variabel disiplin kerja berpengaruh positif terhadap kepuasan kerja.

\section{METODE PENELITIAN}

\subsection{Lokasi Penelitian}

Lokasi penelitian di SMA Negeri 6 Banda Aceh. Adapun penelitian yang dilakukan oleh penulis mengambil lokasi di Jalan Tgk. Cot Aron Desa Lamjabat.

\subsection{Populasi dan Sampel Penelitian}

Populasi dari penelitian ini adalah semua guru di SMA Negeri 6 Banda Aceh yang berjumlah 40 orang. Sampel yang digunakan dalam penelitian ini adalah sampel jenuh.

\subsection{Definisi dan Pengukuran Operasional Variabel \\ 3.3.1. Definisi Operasional}

Variabel penelitian adalah hal-hal yang dapat membedakan atau membawa variasi pada nilai Penelitian ini menguji dua variabel yaitu variabel independen dan varibel dependen. Variabel independen dalam penelitian ini adalah kompensasi dan disiplin kerja, sedangkan variabel dependen adalah kinerja.

Definisi operasional adalah operasionalisasi konsep agar dapat diteliti atau diukur melalui gejala-gejala yang ada. Definisi operasional yang digunakan untuk penelitian ini kemudian diuraikan menjadi indikator empiris yang meliputi:

\section{A. Kompensasi}

Kompensasi adalah pendapatan karyawan berbentuk uang atau barang baik langsung berupa gaji, insentif, bonus, tunjangan, buku-buku, seragam dan makan siang maupun tidak langsung berupa jaminan kesehatan dan uang pensiun di SMA Negeri 6 Banda Aceh.

\section{B. Disiplin Kerja}

Disiplin adalah suatu kondisi yang tercipta dan terbentuk melalui proses perilaku, melalui pelajaran, kepatuhan, ketaatan, kesetiaan, dan hormat kepada ketentuan / peraturan norma yang berlaku di SMA Negeri 6 Banda Aceh.

\section{Kinerja Guru}


Kinerja Guru berasal kata job performance / actual permance (prestasi kerja atau prestasi sesungguhnya yang dicapai oleh seseorang). Jadi kinerja bisa diartikan sebagai prestasi yang nampak sebagai bentuk keberhasilan kerja pada diri seseorang. Keberhasilan kinerja juga ditentukan dengan pekerjaan serta kemampuan seseorang pada kualitas kerja, ketepataan kerja, inisiatif, kemampuan dalam bekerja, dan komunikasi di SMA Negeri 6 Banda Aceh.

\subsection{Teknik Analisa Data}

Agar data yang diperlukan dapat dipergunakan secara efektif dan efisien, maka perlu ditetapkan : data apa saja yang dibutuhkan, jenis data apa saja yang perlu ditetapkan, dimana sumber datanya, dan dengan teknik apa saja data dikumpulkan.

\section{A. Jenis Data dan Sumber Data}

Data pada penelitian ini terdiri dari data primer dan data skunder.

1. Data primer yaitu data penelitian yang diperoleh langsung dari sumber asli (tidak melalui sumber perantara) dan data dikumpulkan secara khusus untuk menjawab pertanyaan penelitian. Data primer ini khusus dikumpulkan untuk kebutuhan riset yang sedang berjalan. Data primer dalam penelitian ini adalah data tentang profil sosial dan indentifikasi responden, berisi data responden yang berhubungan dengan identitas responden dan keadaan sosial seperti: usia, jenis kelamin, pendidikan terakhir, dan masa kerja, selanjutnya yang berkaitan dengan pengaruh kompensasi, disiplin kerja, terhadap kinerja.

2. Data sekunder adalah data yang merupakan sumber data penelitian secara tidak langsung, melalui perantara (diperoleh dan dicatat oleh pihak lain). Data sekunder umumnya berupa bukti, catatan atau laporan historis yang telah tersusun dalam arsip (data dokumenter) yang di publikasikan dan yang tidak di publikasikan. Data sekunder dalam penelitian ini meliputi: biodata guru di SMA Negeri 6 Banda Aceh.

\section{B. Teknik Pengambilan Data}

Dalam merencanakan pengambilan data, konsepnya disesuaikan dengan latar belakang masalah, rumusan masalah, dan tujuan penelitian. Dalam merencanakan pengambilan sampel penelitian dilakukan sampel jenuh, karena semua populasi dijadikan obyek penelitian ini sehingga digunakan metode sensus sejumlah 40 guru di SMA Negeri 6 Banda Aceh yang dijadikan responden.

1. Metode angket

Penelitian ini, metode pengumpulan data primer dilakukan dengan menggunakan metode angket tertutup. Untuk mendapatkan data tentang dimensi-dimensi dari konstruk-konstruk yang sedang dikembangkan dalam penelitian ini. Pertanyaan dalam angket tertutup dibuat dengan menggunakan skala likert dalam interval 1-5. untuk katagori pertanyaan dengan jawaban sangat tidak setuju dengan nilai 1 (satu) sampai dengan sangat setuju dengan nilai 5 (lima) dan begitu juga dengan interval 1-5, untuk kategori pertanyaan dengan jawaban selalu dengan nilai 1 (satu) sampai denga tidak pernah nilai 5 (lima). Teknik distribusi angket dilakukan dengan bertatap muka secara langsung dengan guru SMA Negeri 6 Banda Aceh, sekaligus melakukan wawancara singkat tentang data-data yang mungkin mendukung dan memperkuat proses pengambilan data dalam penelitian. Untuk pertanyaan kinerja guru diisi oleh kepala sekolah SMA Negeri 6 Banda Aceh.

2. Wawancara

Selain metode angket juga dugunakan metode wawancara untuk mendukung akurasi dan kelengkapan kuesioner yang tersebar. Wawancara juga digunakan untuk memperluas 
cakrawala peneliti tentang data-data lain yang tidak terformulasi dalam kuesioner. Selain itu, wawancara juga digunakan untuk melengkapi data yang terkumpul melalui kuesioner.

\section{Metode Analisis}

Alat analisi yang akan digunak oleh peneliti adalah regresi berganda. Untuk menganalisis dan mengetahui tingkat signifikat dan variabel manakah yang sangat berpengaruh terhadap kinerja guru yang digunakan reglesi korelasi berganda. Dengan metode ini dapat dilihat besarnya hubungan antara $\mathrm{X}_{1}$ dengan $\mathrm{Y}: \mathrm{X}_{2}$ dengan $\mathrm{Y}$. Dan untuk mencari besarnya $\mathrm{X}_{1}, \mathrm{X}_{2}$, terhadap Y secara bersama-sama digunakan korelari berganda.

Korelasi berganda merupakan alat ukur untuk mengetahui pertautan antara variabel terikat (Y) dengan beberapa variabel bebas (X) secara serempak dengan menggunakan perhitungan komputer program SPSS.

Adapun dengan perhitungan menggunakan rumus seperti dibawah ini :

$\mathrm{Y}=\mathrm{a}_{0}+\mathrm{a}_{1} \mathrm{X}_{1}+\mathrm{a}_{2} \mathrm{X}_{2}+\varepsilon$

Dimana :

$\begin{array}{ll}\mathrm{a}_{0} & : \text { Konstanta Y } \\ \mathrm{a}_{1}, \mathrm{a}_{2} & : \text { Koefisien Regresi Y } \\ \mathrm{Y} & : \text { Kinerja Guru } \\ \mathrm{X}_{1} & : \text { Kompensasi } \\ \mathrm{X}_{2} & : \text { Disiplin Kerja } \\ \mathcal{E} & : \text { Error }\end{array}$

\subsection{Pengujian Validitas dan Reliabilitas}

Dalam analisis kuantitatif ini dilakukan pengujian validitas dan pengujian reliabilitas mengenai poin-poin kuesioner melalui skor data yang telah diperoleh dari jawaban responden.

\subsubsection{Pengujian Validitas}

Suatu kuesioner dikatakan valid (sah) jika poin pertanyaan pada suatu kuesioner mampu untuk mengungkapkan sesuatu yang akan diukur oleh kuesioner tersebut. Untuk menggunakan valid atau tidaknya kuesioner dalam penelitian menggunakan perbandingan antara koefisien kolerasi $r$ tabel. Poin kuesioner dikatakan valid $r=$ lebih besar dari $r$ tabel dan sebaliknya nilai $r$ $=$ lebih kecil dari $r$ tabel maka dikatakan poin pertanyaan tidak valid. Menggunakan pengujian statistik kolerasi person.

\subsubsection{Pengujian Reliabilitas}

Reliabilitas merupakan ukuran suatu kestabilan dan konsistensi responden dalam menjawab hal yang berkaitan dengan poin-poin pertanyaan yang merupakan dimensi suatu variabel dan di susun dalam bentuk kuesioner. Poin kuesioner dikatakan reliabel atau pantas apabila jawaban seseorang terhadap kuesioner adalah konsisten. Dalam penelitian ini untuk menentukan kuisioner reliabel atau tidak reliabel menggunakan alpha cronbach. Kuesioner dikatakan reliabel jika alpha cronbach $>0,60$ dan tidak reliabel jika sama dengan atau dibawah 0,60 .

\subsection{Pengujian Hipotesis}

Pengujian hipotesis dalam penelitian ini dilakukan dengan pengujian statistik, yaitu : Uji hipotesis dengan uji signifikansi atau tidak terhadap variabel dependen, untuk menginterprestasikan hasil perhitungan uji signifikansi, digunakan kriteria berikut :

Bila sig. $\leq \alpha$, maka Ho ditolak

Bila sig. $>\alpha$, maka Ho diterima

Dalam hal ini digunakan $\alpha=5 \%$, untuk menunjukan adanya nilai koefisien regresi bersifat signifikansi atau tidak. 


\section{HASIL DAN PEMBAHASAN}

\subsection{Pembahasan}

\subsubsection{Analisis Deskriptif Data Responden}

Pada tahap ini dilakukan analisis terhadap guru SMA Negeri 6 Banda Aceh dengan jumlah responden sebanyak 40 orang. Untuk lebih jelasnya data disajikan dalam tabel berikut.

\section{A. Jenis Kelamin}

Dari hasil pengumpulan data diketahui bahwa sebagian besar guru adalah wanita yaitu $67,5 \%$. Sedangkan pria 32,5\%. Hal itu sesuai dengan populasi dimana mayoritas gurunya adalah perempuan.

\section{B. Pendidikan}

Dari hasil pengumpulan data diketahui bahwa dapat dilihat bahwa guru paling banyak berpendidikan S1 yaitu $87,5 \%$. Hal ini disebabkan syarat untuk menjadi guru minimal berijazah S1. Adapun yang berijazah S2 sebanyak 12,5\%.

\section{Masa Kerja}

Dari hasil pengumpulan data diketahui bahwa bahwa masa kerja guru yang paling banyak adalah 10-20 tahun yaitu 47,5\%.

\section{Usia Responden}

Dari hasil pengumpulan data diketahui bahwa usia responden yang paling banyak adalah antara 36-45 tahun yaitu 50\%, disusul guru yang berusia 26-35 tahun 30\%. Hal ini berarti bahwa karyawan saat ini sebagian besar masih dalam usia yang produktif dan kemungkinan untuk bisa dikembangkan.

\subsection{Hasil Uji Kualitas Data}

\section{A. Uji Validitas}

Setelah pretes yang dilakukan terhadap 40 buah kuesioner penelitian selesai dilakukan atau sebanyak 40 orang responden, selanjutnya dilakukan uji validitas dengan menggunakan sofware SPSS versi 21. Berdasarkan hasil perhitungan dengan menggunakan SPSS versi 21, dikatakan valid jika nilai sig lebih kecil dari nilai $\alpha=5 \%$ (signifikan 0.05). Maka dapat disimpulkan bahwa semua variabel-variabel penelitian adalah sahih (valid) dan kuesioner penelitian dapat digunakan untuk mengumpulkan data selanjutnya. Uji validitas digunakan untuk mengetahui kelayakan butir-butir dalam suatu daftar pertanyaanpertanyaan dalam mendefinisikan suatu variabel.

Dari hasil pengolahan data variabel kompensasi terdiri dari 10 pertanyaan, semua butir pertanyaan mempunyai nilai sig lebih kecil dari 0.05, maka dapat disimpulkan bahwa semua butir pertanyaan valid. Artinya semua butir pertanyaan dapat dipakai sebagai alat ukur dalam penelitian ini.

Dari hasil pengolahan data variabel disiplin kerja terdiri dari 8 pertanyaan, semua butir pertanyaan mempunyai nilai sig lebih kecil dari 0.05, maka dapat disimpulkan bahwa semua butir pertanyaan valid. Artinya semua butir pertanyaan dapat dipakai sebagai alat ukur dalam penelitian ini.

Dari hasil pengolahan data variabel kinerja terdiri dari 11 pertanyaan, semua butir pertanyaan mempunyai sig lebih kecil dari 0.05 , maka dapat disimpulkan bahwa semua butir pertanyaan valid. Artinya semua butir pertanyaan dapat dipakai sebagai alat ukur dalam penelitian ini. 


\section{B. Uji Reliabilitas}

\section{Uji Reliabilitas Variabel Kompetensi, Kompensasi, Disiplin Kerja, Kinerja dan}

\section{Kepuasan Kerja.}

Setelah pretes yang dilakukan terhadap 40 buah kuesioner penelitian selesai dilakukan atau sebanyak 40 orang responden, selanjutnya dilakukan uji realibilitas dengan menggunakan sofware SPSS 21. Berdasarkan hasil perhitungan dengan menggunakan SPSS, dikatakan reliabel jika nilai Cronbach's Alpha lebih besar dari 0.60 maka kuesioner dikatakan reliabel.

Dari hasil pengolahan data variabel kompensasi mempunyai nilai Cronbach's Alpha sebesar 0.899, variabel disiplin kerja mempunyai nilai Cronbach's Alpha sebesar 0.894, variabel kinerja mempunyai nilai Cronbach's Alpha sebesar 0.914. Dengan hasil ini maka dapat dinyatakan bahwa alat ukur pada variabel kompensasi, disiplin kerja, dan kinerja sangat reliabel berdasarkan batasan pada interval pada pengukuran reliabilitas.

\subsection{Analisis Deskriptif}

Variabel Kompensasi, Disiplin Kerja, dan Kinerja.

Berikut ini adalah hasil analisis data deskriptif variabel kompensasi, disiplin kerja, dan kinerja dari responden yang berjumlah 40 orang, dapat dilihat pada tabel dibawah ini. Analisis deskriptifnya dapat dijelaskan sebagai berikut.

\begin{tabular}{|c|c|c|}
\hline No. & Pertanyaan & Rata-rata \\
\hline 1 & Gaji yang saya terima sesuai dengan beban dan resiko lain. & 3.37 \\
\hline 2 & Gaji yang saya terima sudah lebih baik dari sekolah lain. & 3.65 \\
\hline 3 & $\begin{array}{l}\text { Insentif yang diberikan sekolah sudah didasarkan pada prinsip } \\
\text { keadilan. }\end{array}$ & 3.62 \\
\hline 4 & $\begin{array}{l}\text { Bonus yang diberikan sekolah sudah didasarkan dengan } \\
\text { penyelesaian pekerjaannya. }\end{array}$ & 3.75 \\
\hline 5 & Tunjangan yang diberikan sekolah sudah mencukupi. & 3.65 \\
\hline 6 & Seragam yang diberikan sekolah sudah mencukupi. & 3.57 \\
\hline 7 & Buku-buku yang diberikan sekolah sudah memadai. & 3.32 \\
\hline 8 & Makan siang yang diberikan sekolah sudah memadai. & 3.67 \\
\hline 9 & Jaminan kesehatan sudah cukup memadai. & 3.57 \\
\hline 10 & Uang pensiun yang diberikan sekolah sudah mencukupi. & 3.50 \\
\hline \multicolumn{2}{|r|}{ Rata-rata } & 3.57 \\
\hline
\end{tabular}

Dari 10 pertanyaan dapat dilihat bahwa pertanyaan no 4 "Bonus yang diberikan sekolah sudah didasarkan dengan penyelesaikan pekerjaan saya" memperoleh nilai rata-rata terbesar yaitu 3.75, nilai tersebut dapat diartikan bahwa bonus yang diberikan sekolah sudah tergolong baik, karena sekolah sudah memperhatikan kepentingan guru dengan bonus yang diberikan. Sedangkan pertanyaan no 7 "Buku-buku yang diberikan sekolah sudah memadai", memperoleh nilai rata-rata terendah yaitu 3.32, guru merasakan bahwa bukubuku yang diberikan sekolah masih belum sesuai sebagaimana yang diharapkan, sebagai guru yang harus selalu mengupdate pengetahuan dengan buku-buku terbaru untuk kepentingan mengajar. Secara rata-rata untuk variabel kompensasi secara keseluruhan tergolong baik dengan perolehan nilai rata-rata 3.57.

\begin{tabular}{|c|l|c|}
\hline No. & \multicolumn{1}{|c|}{ Pertanyaan } & Rata-rata \\
\hline 1 & Saya berusaha hadir disekolah lebih awal sebelum jam mengajar dimulai. & 3.77 \\
\hline 2 & Pimpinan saya memberikan keteladanan yang baik kepada bawahannya. & 3.22 \\
\hline 3 & Saya bersedia diberikan sanksi bila tidak mematuhi tata tertib. & 3.80 \\
\hline 4 & Saya dalam bekerja selalu bertegur sapa kepada atasan dan sesama guru. & 4.05 \\
\hline
\end{tabular}




\begin{tabular}{|c|l|c|}
\hline 5 & $\begin{array}{l}\text { Dalam bekerja saya selalu melakukan komunikasi dengan atasan setiap } \\
\text { mengalami masalah. }\end{array}$ & 3.42 \\
\hline 6 & Saya diharuskan mentaati peraturan yang berlaku disekolah. & 3.47 \\
\hline 7 & Saya mengerjakan semua pekerjaan sekolah sampai tuntas. & 3.35 \\
\hline 8 & $\begin{array}{l}\text { Saya selalu menjaga dan menjunjung tinggi norma-norma yang berlaku } \\
\text { disekolah. }\end{array}$ & 3.17 \\
\hline \multicolumn{2}{|c|}{ Rata-rata } & 3.54 \\
\hline
\end{tabular}

Dari 8 pertanyaan dapat dilihat bahwa pertanyaan no 4 "Saya dalam bekerja selalu bertegur sapa kepada atasan dan sesama guru" memperoleh nilai rata-rata terbesar yaitu 4.05, hal ini menunjukan bahwa guru sudah melakukan hubungan kerja yang baik dengan atasan maupun rekan sesama guru. Sedangkan pertanyaan no 8 "Saya selalu menjaga dan menjunjung tinggi norma-norma yang berlaku disekolah", memperoleh nilai terendah yaitu 3.17 , hal ini disebabkan belum adanya kesadaran guru dalam menjunjung tinggi normanorma yang berlaku didalam lingkungan sekolah. Secara rata-rata untuk variabel disiplin kerja secara keseluruhan tergolong baik dengan perolehan nilai rata-rata 3.54.

\begin{tabular}{|c|l|c|}
\hline No. & \multicolumn{1}{|c|}{ Pertanyaan } & $\begin{array}{c}\text { Rata- } \\
\text { rata }\end{array}$ \\
\hline 1 & Guru ini sebelum mengajar menyiapkan rencana pembelajaran. & 3.22 \\
\hline 2 & Guru ini menilai pekerjaan siswa dengan teliti. & 3.47 \\
\hline 3 & $\begin{array}{l}\text { Guru ini dalam menjelaskan materi pembelajaran, sangat hati-hati untuk } \\
\text { menghindari penjelasan konsep yang keliru. }\end{array}$ & 3.55 \\
\hline 4 & $\begin{array}{l}\text { Guru ini dalam menjelaskan materi pelajaran sesuai dengan karakteristik } \\
\text { siswa dengan contoh-contoh pada kehidupan riil yang dialami siswa sehari- } \\
\text { hari. }\end{array}$ & 3.50 \\
\hline 5 & $\begin{array}{l}\text { Guru ini menyelesaikan program pengajaran sesuai dengan kalender } \\
\text { akademik. }\end{array}$ & 4.15 \\
\hline 6 & Guru ini dalam mengajar berusaha menggunkan media pembelajaran. & 4.12 \\
\hline 7 & $\begin{array}{l}\text { Guru ini menggunakan metode pembelajaran dikelas dalam bentuk } \\
\text { kelompok. }\end{array}$ & 3.40 \\
\hline 8 & Guru ini mampu memimpin kelas dengan baik. & 3.50 \\
\hline 9 & Guru ini mampu mengelola kelas dengan baik. & 3.65 \\
\hline 10 & Guru ini melaksanakan bimbingan belajar dengan siswa. & 3.82 \\
\hline 11 & $\begin{array}{l}\text { Guru ini dalam mengajar mengomunikasikan materi-materi baru sesuai } \\
\text { dengan perkembangan kurikulum }\end{array}$ & 3.27 \\
\hline & \multicolumn{1}{|c|}{ Rata-rata } & 3.60 \\
\hline
\end{tabular}

Dari 11 pertanyaan dapat dilihat bahwa pertanyaan no 5 "Guru ini menyelesaikan program pengajaran sesuai dengan kaleder akademik" memperoleh nilai rata-rata terbesar yaitu 4.15, hal ini menunjukan bahwa guru sudah melakasanakan program pengajaran tapat pada waktunya sesuai dengan kalender akademik yang dibuat sekolah. Sedangkan pertanyaan no 1 "Guru ini sebelum mengajar menyiapkan rencana pembelajaran" memperoleh nilai ratarata terendah yaitu 3.22, hal ini dikarenakan belum adanya kesadaran dari guru untuk menyiapkan rencana pembelajaran untuk mengajar. Secara keseluruhan untuk variabel kinerja sudah baik dengan rata-rata nilai 3.60.

\subsubsection{Analisis Regresi Linier Berganda}

Analisis kuantitatif penelitian dilakukan menggunakan analisi regresi linier berganda dengan bantuan software SPSS versi 21.

\subsubsection{Kompensasi dan disiplin kerja terhadap kinerja}


Analisis kuantitatif penelitian dilakukan menggunakan analisi regresi linier berganda dengan bantuan software SPSS versi 21 Regresi antara variabel kompensasi dan disiplin kerja terhadap kinerja dapat digambarkan dalam pengolahan data sebesar angka $\mathrm{R}^{2}$ (koefisien determinasi) sebesar 0.5072 (lihat tabel summary pada lampiran 16). Hal ini menunjukan bahwa besarnya variasi yang memberikan pengaruh bersama-sama antara variabel kompensasi dan disiplin kerja terhadap kinerja sebesar $50.7 \%$ atau sisanya $3 \%$ dipengaruh faktor-faktor lain diluar ketiga variabel independen tersebut.

Tabel Hasil Uji Regrasi Linier Berganda Kompensasi, Disiplin Kerja Terhadap Kinerja Coefficients $^{\mathrm{a}}$

\begin{tabular}{|c|c|c|c|c|c|c|}
\hline \multirow{2}{*}{\multicolumn{2}{|c|}{ Model }} & \multicolumn{2}{|c|}{ Unstandardized Coefficients } & \multirow{2}{*}{$\begin{array}{c}\begin{array}{c}\text { Standardized } \\
\text { Coefficients }\end{array} \\
\text { Beta }\end{array}$} & \multirow[b]{2}{*}{$\mathrm{t}$} & \multirow[b]{2}{*}{ Sig. } \\
\hline & & $\mathrm{B}$ & Std. Error & & & \\
\hline \multirow{3}{*}{1} & (Constant) & 9,873 & 5,819 & & 1,697 & ,098 \\
\hline & KOMPENSASI & ,248 & 104 & ,295 & 2,383 & 022 \\
\hline & DISIPLINKERJA & ,738 & 154 &, 593 & 4,793 &, 000 \\
\hline
\end{tabular}

a. Dependent Variable: KINERJA

Tabel diatas menunjukan bahwa ketiga variabel independen berpengaruh secara signifikan terhadap kinerja. Untuk mengetahui besar pengaruh dari tiap variabel independen terhadap variabel dependennya, dapat dilihat dari nilai-nilai pada kolom beta, bahwa pengaruh terbesar adalah variabel disiplin kerja sebesar 0,593. Hasil pengolahan data dari tabel hasil uji regresi linier berganda didapatkan variabel disiplin kerja (X2) memiliki nilai signifikan 0,000 yang lebih kecil dari nilai $\alpha$ sebesar 0,05 , maka variabel disiplin kerja berpengaruh signifikan terhadap kinerja. Pengaruh kompensasi dengan nilai beta 0,295. Hasil pengolahan data dari tabel hasil uji regresi linier berganda didapatkan variabel kompensasi (X1) memiliki nilai signifikan 0,022 yang lebih kecil dari nilai $\alpha$ sebesar 0,05 , maka variabel kompensasi berpengaruh signifikan terhadap kinerja. Maka persamaan regresi liniernya adalah.

$$
Y=9.873+0.248 \times 1+0.738 \times 2+\varepsilon
$$

Nilai konstanta kinerja sebesar 9.873 menunjukan nilai murni variabel terikat tanpa dipengaruhi variabel kompensasi dan disiplin kerja.

Hasil persamaan koefisien regresi variabel kompensasi adalah 0.248 , hal ini konstan maka setiap peningkatan variabel kompensasi maka dapat diprediksi bahwa variabel kinerja ikut naik 0.248 . Koefisien regresi variabel disiplin kerja adalah 0.738 , hal ini konstan maka setiap peningkatan variabel disiplin kerja naik maka dapat diprediksi bahwa variabel kinerja ikut naik 0.738 .

\subsection{Pembahasan Hasil Penelitian}

Dalam penelitian ini, analisis deskriptif menunjukan bahwa jawaban responden mengenai variabel kompensasi, disiplin kerja dan kinerja secara rata-rata adalah baik. Untuk variabel kompensasi secara keseluruhan jawaban responden baik dengan rata-rata nilai 3.57, hal ini menunjukan bahwa kompensasi sudah baik, akan tetap agar kinerja dan kepuasan kerja guru meningkat maka pihak sekolah harus lebih memperhatikan kompensasi dengan cara meningkatkan pemberian bonus, insentif guru atau menaikan gaji guru. Untuk variabel disiplin kerja secara keseluruhan jawaban responden baik dengan rata-rata nilai 3.54, hal ini menunjukan bahwa disiplin kerja guru baik, akan tetapi disipin kerja harus lebih ditingkatkan oleh para guru seperti tidak datang terlambat, teliti, dan taat pada peraturan sekolah agar kinerja dan kepuasan kerja guru meningkat. Untuk variabel kinerja secara keseluruhan jawaban responden baik dengan rata-rata nilai 3.60, artinya kinerja guru sudah 
baik namun masih bisa ditingkatkan lagi dengan meningkatkan kualitas kerja, ketepatan dalam bekerja, inisiatif dalam bekerja komunikasi yang baik kepada atasan dan sesama rekan kerja.

Dalam penelitian ini, dihasilkan bahwa variabel kompensasi, disiplin kerja berpengaruh terhadap kinerja guru. Hasil penelitian ini sejalan dengan hasil penelitian yang dilakukan oleh Bagus Triyatno yang menyatakan bahwa kompensasi, disiplin dan pelatihan berpengaruh terhadap kinerja, dan hasil penelitian yang dilakukan oleh Endang Ilyas yang menyatakan bahwa kompensasi, promosi dan shift kerja berpengaruh terhadap kinerja dan kepuasan kerja.

Dari model pertama menunjukan bahwa variabel disiplin kerja menjadi variabel yang paling dominan pengaruhnya terhadap kinerja, karena disiplin merupakan fungsi operatif dari manajemen sumber daya manusia yang terpenting. Semakin baik disiplin kerja guru maka semakin tinggi prestasi kerja dan kinerja guru, tanpa disiplin yang tinggi sulit bagi sekolah mencapai hasil kerja yang optimal.

\section{KESIMPULAN DAN SARAN}

\subsection{Kesimpulan}

Berdasarkan hasil analisis data dan pembahasan pada bab terdahulu, maka dapat diambil kesimpulan sebagai berikut:

1. Dalam penelitian ini, analisis deskriptif menunjukan bahwa jawaban responden mengenai variabel kompensasi, disiplin kerja dan kinerja secara rata-rata adalah baik. Untuk variabel kompensasi secara keseluruhan jawaban responden baik dengan ratarata nilai 3.57, hal ini menunjukan bahwa kompensasi sudah baik, akan tetap agar kinerja dan kepuasan kerja guru meningkat maka pihak sekolah harus lebih memperhatikan kompensasi dengan cara meningkatkan pemberian bonus, insentif guru atau menaikan gaji guru. Untuk variabel disiplin kerja secara keseluruhan jawaban responden baik dengan rata-rata nilai 3.54, hal ini menunjukan bahwa disiplin kerja guru baik, akan tetapi disipin kerja harus lebih ditingkatkan oleh para guru seperti tidak datang terlambat, teliti, dan taat pada peraturan sekolah agar kinerja dan kepuasan kerja guru meningkat. Untuk variabel kinerja secara keseluruhan jawaban responden baik dengan rata-rata nilai 3.60, artinya kinerja guru sudah baik namun masih bisa ditingkatkan lagi dengan meningkatkan kualitas kerja, ketepatan dalam bekerja, inisiatif dalam bekerja komunikasi yang baik kepada atasan dan sesama rekan kerja.

2. Dalam penelitian ini, dihasilkan bahwa variabel kompensasi, disiplin kerja berpengaruh terhadap kinerja guru. Hasil penelitian ini sejalan dengan hasil penelitian yang dilakukan oleh Bagus Triyatno yang menyatakan bahwa kompensasi, disiplin dan pelatihan berpengaruh terhadap kinerja, dan hasil penelitian yang dilakukan oleh Endang Ilyas yang menyatakan bahwa kompensasi, promosi dan shift kerja berpengaruh terhadap kinerja dan kepuasan kerja.

3. Dari model pertama menunjukan bahwa variabel disiplin kerja menjadi variabel yang paling dominan pengaruhnya terhadap kinerja, karena disiplin merupakan fungsi operatif dari manajemen sumber daya manusia yang terpenting. Semakin baik disiplin kerja guru maka semakin tinggi prestasi kerja dan kinerja guru, tanpa disiplin yang tinggi sulit bagi sekolah mencapai hasil kerja yang optimal.

\subsection{Saran}

Dengan mempertimbangkan hasil penelitian ini, sebagai sumbangan pemikiran bagi ilmu pengetahuan, khususnya bagi menejemen sumber daya manusia untuk memecahkan masalah kinerja dan kepuasan kerja guru di sekolah, maka dengan ini disarankan sebagai berikut : 
1. Optimalisasi kinerja guru melalui penetapan sistem kompensasi yang memperhatikan prinsip keadilan dalam pemberian kompensasi baik langsung maupun tidak langsung dan sekolah harus memperhatikan pemberian buku-buku yang selalu update sesuai dengan perkembangan kurikulum kepada para guru untuk menunjang pembelajaran disekolah.

2. Optimalisasi kinerja melalui peningkatan disiplin kerja. Disiplin kerja yang tinggi bisa dicapai dengan langkah mematuhi dan menjungjung tinggi norma-norma yang berlaku dan telah disepakati bersama dalam sekolah.

\section{DAFTAR PUSTAKA}

Baedhowi. 2007. Tantangan Peningkatan Profesionalisme Tenaga Pendidik pada Era UU Pemerintah RI no.14 Tahun 2005.Tentang UU Guru dan Dosen. Jakarta.

Bangun, Wilson. 2012. Manajemen Sumber Daya Manusia. Erlangga. Jakarta.

Byars, L. L., and L.W, Rue. 2010. Human Resources Management. Mc Graw Hill, New York

Darmawan. 2013. Metode Penelitian Kuantitatif. Bandung : Remaja Rosdakarya.

Dessler, Garry. 2010. Manajemen Sumber Daya Manusia. Buku 1. Indeks, Jakarta.

Gibson, et al. 2012. Manajemen Kinerja. Jakarta : Erlangga.

Gunawan, M. Ali. 2012. Penilaian Kinerja Guru. www.slideshare.net.tgl 10 Desember, Jakarta

Hasibuan, M. 2012. Manajemen Sumber Daya Manusia. Bumi Aksara, Indonesia Jakarta.

Mathis dan Jackson. 2010. Manajemen Sumber Daya Manusia. Penterjemah Jimmy Saddel dan Bayu Prawira Hie. Jakarta : Penerbit PT. Salemba Empat.

Mondy, R.W., Noe, R.M., and Premaux, S.R. 2010. Human Resources Management. Prentice Hall, New York.

Nawawi, H. Hadari, 2011, Manajemen Sumber Daya Manusia untuk Bisnis yang Kompetitif, Yogyakarta:Gajah Mada University Press.

Nurmianto dan Wijaya. 2011. Manajemen Kualitas Jasa, Cetakan ke-1, Kembangan-Jakarta Barat : PT, Indeks.

Prijodarminto, Soegeng. 2004. Disiplin Kiat Menuju Sukses. Pradnya Paramita : Jakarta.

Rivai, Veithzal. 2011. Manajemen Sumber Daya Manusia Untuk Perusahaan. Jakarta : PT. Raja Grafindo Persada.

Sinambela, Lijan. 2012. Kinerja Pegawai: Teori, Pengukuran dan Implikasi. Yogyakarta: Graha Ilmu.

Sondang P, Siagian. 2012. Kiat Meningkatkan Produktivitas Kerja. Jakarta. PT Rineka Cipta. Sutrisno, Edy. 2013. Manajemen Sumber Daya Manusia. Jakarta : Kencana Prenada Media Group. 
Torang, Syamsir. 2013. Organisasi dan Manajemen (Perilaku, Struktur, Budaya \& Perubahaan Organisasi. Alfabeta. Bandung.

Wibowo. 2009. Manajemen Kinerja (edisi ke 3). Rajawali Press, Jakarta

Wirawan. 2012. Evaluasi Kinerja Manajemen Sumber Daya Manusia, Jakarta : Salemba Empat. 